\title{
EVALUASI SPO PELAYANAN FARMASI KLINIK DI APOTEK BERDASARKAN PETUNJUK TEKNIS PELAYANAN KEFARMASIAN DI APOTEK TAHUN 2019
}

\author{
Zam Zam Elfrida K ${ }^{1^{*}}$, Yulian Wahyu Permadi ${ }^{2}$, Ainun Muthoharoh ${ }^{3}$, Dwi Bagus Pambudi ${ }^{4}$ \\ *1, 2,3,4 Program Studi Farmasi, Fakultas Ilmu Kesehatan, Universitas Muhammadiyah Pekajangan Pekalongan, \\ Indonesia \\ e-mail : ${ }^{* 1}$ zamzam.pml19@gmail.com, ${ }^{2}$ yulian_wahyu_permadi@yahoo.com, 3 ainun.muthoharoh@gmail.com, \\ ${ }^{4}$ dwibagus589@gmail.com
}

\begin{abstract}
ABSTRAK
Pengkajian resep, dispensing, pelayanan informasi obat, konseling, pelayanan kefarmasian dirumah, pemantauan terapi obat dan memonitoring efek samping obat merupakan bagian dari tugas apoteker farmasi klinik yang tercantum dalam petunjuk teknis standar pelayanan kefarmasian di apotek tahun 2019. Penelitian ini bertujuan untuk mengevaluasi Standar Prosedur Operasional tentang pelayanan farmasi klinik di apotek se-Kabupaten Pemalang. Metode penelitian yang digunakan yaitu dengan pendekatan Functional Analysis Survey. Pengambilan sampel dengan cara purposive sampling. Alat ukur penelitian menggunakan kuisioner dan wawancara mendalam. Hasil penelitian menunjukkan bahwa apotek se-Kabupaten Pemalang sudah memiliki SPO pada pelayanan farmasi klinik berdasarkan petunjuk teknis standar pelayanan farmasi klinik di apotek 2019 yaitu SPO Pengkajian dan Pelayanan Resep (96,8\%), SPO Dispensing (80,6\%), SPO Pelayanan Informasi Obat (77,4\%), SPO Konseling (80,6\%), SPO Pelayanan Kefarmasian di Rumah (64,5\%), SPO Pemantauan Terapi Obat (67,7\%), SPO MESO (32,3\%).
\end{abstract}

Kata Kunci: Apotek, Pelayanan Farmasi Klinik, SPO

\begin{abstract}
Reviewing prescriptions, dispensing, drug information services, counseling, pharmaceutical services at home, monitoring drug therapy and monitoring drug side effects are part of the duties of clinical pharmacy pharmacists listed in the technical guidelines for standard pharmaceutical services in pharmacies in 2019. This study aims to evaluate Standard Procedures. Operational on clinical pharmacy services at pharmacies throughout Pemalang Regency. The research method used is the Functional Analysis Survey approach. Sampling by purposive sampling. The measuring instrument of the research used questionnaires and in-depth interviews. The results showed that pharmacies throughout Pemalang Regency already had SOPs for clinical pharmacy services based on the technical guidelines for standard clinical pharmacy services at pharmacies in 2019, namely SPO for Assessment and Prescription Services (96.8\%), SPO Dispensing (80.6\%), SPO Services Drug Information (77.4\%), SOP for Counseling (80.6\%), SOP for Pharmaceutical Services at Home (64.5\%), SOP for Monitoring Drug Therapy (67.7\%), MESO SOP (32.3\%).
\end{abstract}

Keyword: Clinical Pharmacy Services, SPO, Pharmacies

\section{PENDAHULUAN}

Standar Operasional Prosedur (SPO) adalah serangkaian instruksi kerja tertulis yang sudah terdokumentasi mengenai proses penyelenggaraan bagaimana dan kapan harus dilakukan, dimana dan oleh siapa dilakukan untuk meningkatkan kualitas dari sebuah proses atau produk yang akan dibuat dan dilaksanakan [1]. Tanpa SPO apotek tidak memiliki suatu media sebagai pedoman yang pasti dan peluang unkonsistensi dalam menjalankan proses aktivitas apotek sangat mungkin terjadi sehingga kualitas kerja apotek tidak maksimal [2]. 
Kegiatan pelayanan farmasi yang awalnya berfokus pada pengelolaan obat sebagai komoditi harus diubah menjadi pelayanan yang komprehensif [3]. Hal ini sudah diatur dalam Petunjuk Teknis Standar Pelayanan Kefarmasian di apotek. Pelayanan farmasi klinik meliputi pengkajian dan pelayanan resep, dispensing, pelayanan informasi obat, konseling, pelayanan kefarmasian di rumah, pemantauan terapi obat dan memonitoring efek samping obat [4].

Berdasarkan penjelasan yang dipaparkan dapat menjadi dasar untuk melakukan penelitian tentang standar operasional prosedur tentang pelayanan farmasi klinik di apotek se-Kabupaten Pemalang. Tujuan dari penelitian ini untuk evaluasi suatu SPO yang tepat untuk proses seperti pengkajian resep, dispensing, pelayanan informasi obat, konseling, pelayanan kefarmasian di rumah, pemantauan terapi obat dan monitoring efek samping obat, sehingga dapat memberikan pelayanan yang maksimal kepada masyarakat dan dapat meningkatkan kualitas hidup pasien.

\section{METODE PENELITIAN}

Metode yang digunakan yaitu jenis penelitian deskriptif prospektif yang menjelaskan tentang Standar Prosedur Operasional (SPO) tentang pelayanan farmasi klinik di apotek. Penelitian deskriptif ini untuk menentukan fakta dengan intervensi yang tepat untuk melukiskan secara akurat [5]. Penelitian ini menggunakan pendekatan functional analysis survey yaitu penelitian dapat mengetahui tentang tugas dan tanggung jawab para petugas kesehatan serta kegiatan kegiatan para petugas [6]. Populasi sasaran dari penelitian ini yaitu Apoteker dan TTK. Pengambilan data dengan membagikan kuisioner tentang pelayanan farmasi klinik dan wawancara mendalam. Sampel penelitian dihitung mengunakan rumus Lwanga dan Lameshow. Pengambilan sampel yang digunakan yaitu secara purposive sampling dengan cara menetapkan ciri ciri khusus yang sesuai dengan penelitiannya.

\subsection{Alat dan Bahan}

Kuisioner dan panduan wawancara

\subsection{Jalannya Penelitian}

Peneliti melakukan pengajuan proposal dan permohonan izin ke LPPM untuk melakukan penelitian, kemudian surat permohonan izin diajukan ke KESBANGPOL Pemalang, BAPEDA, DINKES dan ketua PC IAI. Kemudian mendapatkan data apotek di Kabupaten Pemalang menurut PC IAI yaitu ada 124 apotek, kemudia di hitung menggunakan rumus Lwanga dan Lameshow,1991 didapatkan hasil sampel 31 apotek dengan masing masing kecamatan 3 apotek. Tahap terakhir yaitu pengambilan sampel yang secara purposive sampling, masing masing apotek akan diberikan kuisioner kepada apoteker dan TTK yang berisi SPO tentang pelayanan farmasi klinik.

\subsection{Analisi Data}

Pengolahan data yang dilakukan secara analisis univariat dengan menggunakan aplikasi SPSS versi 23.0. Analisis univariat adalah analisis yang digunakan secara deskriptif dalam setiapvariabel yang ada [7]. Sampel dihitung menggunakan rumus Lwanga dan Lameshow,1991.

$$
\mathrm{n}=\frac{N \cdot Z a^{2} \cdot p \cdot q}{d^{2}(N-1)+Z a^{2} \cdot p \cdot q}
$$

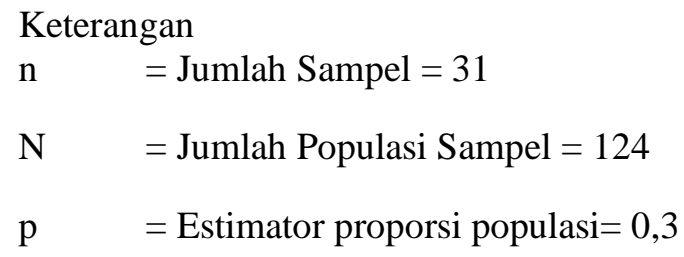




$$
\begin{aligned}
& \mathrm{q} \quad=1-\mathrm{p} \\
& \mathrm{Za}^{2} \quad=\text { Nilai kurva normal yang tergantung dari } \alpha\left(\alpha=5 \% \text { maka } \mathrm{Za}^{2} 1,96\right) \\
& \mathrm{d} \quad=\text { Toleransi kesalahan }=0,1 \\
& \mathrm{n}=\frac{124 \cdot 1,96 \cdot 0,3 \cdot(1-0,3)}{0,1^{2}(124-1)+1,96 \cdot 0,3 \cdot(1-0,3)}=31 \text { Apotek }
\end{aligned}
$$

\section{HASIL DAN PEMBAHASAN}

\subsection{Validitas dan Realibiliti Kuisioner}

Uji validitas bertujuan untuk menunjukkan valid atau tidaknya kuisioner yang dibuat dan dikumpulkan oleh peneliti untuk mencari validitas sebuah sistem[8]. Kuisioner ini dibuat berdasarkan petunjuk teknis standar pelayanan kefarmasian di apotek 2019. Penyebaran kuisioner validasi dilakukan di 10 apotek dengan jumlah responden 30 responden. Pengujian validitas dilakukan dengan menggunakan SPSS VERSI 23.0. Hasil penelitian menunjukkan bahwa kuisioner dinyatakan valid karena korelasinya diatas 0,3 . Menurut Sugiyono (2016) syarat nilai korelasi yang baik yaitu diatas 0,3 sedangkan jika dibawah 0,3 dinyatakan tidak valid [9]. Dari ke 35 soal yang dibuat dan dilakukan validasi hasilnya valid semua, dikatakan valid semua karena soal soal diambil dari petunjuk teknis standar pelayanan farmasi klinik di apotek 2019.

Tabel I. Realibiliti Kuisioner

\begin{tabular}{lll}
\hline $\mathbf{R}_{\text {alpha }}$ & $\mathbf{R}_{\text {korelasi }}$ & Korelasi \\
\hline 0,951 & 0,700 & Realibiliti \\
\hline
\end{tabular}

Uji realibiliti bertujuan untuk mengukur objek yang sama akan menghasilkan data yang sama[7]. Syarat korelasi yang baik dalam realibiliti adalah 0,7 maka dinyatakan cukup. Dan jika korelasinya dibawah 0,7 maka dinyatakan tidak realibiliti. Pada Tabel 1 menunjukan bahwa kuisioner yang telah dibuat oleh peneliti dinyatakan mensugestikan seluruh item realibilitas yang kuat dengan nilai korelasi 0,9 .

\subsection{Gambaran Karakteristik Apoteker}

Tabel II. Gambaran Karakteristik Apoteker

\begin{tabular}{clcl}
\hline No & Variabel & $\begin{array}{l}\text { Jumlah } \\
(\mathbf{n}=\mathbf{3 1})\end{array}$ & $\begin{array}{l}\text { Persentase } \\
(\boldsymbol{\%})\end{array}$ \\
\hline 1 & Status Kepemilikan Apotek & &
\end{tabular}
a. Milik Sendiri
19
61,3
a. Kepemilikan Bersama Dengan Pemodal
b. Milik Pemodal
12
38,7

2 Frekuensi kehadiran dalam 1 minggu
a. Setiap Hari
16
51,6
b. Kurang dari $3 x$ Seminggu
$10 \quad 32,3$
c. 1x Setiap 2 Minggu
$5 \quad 16,1$
d. 1x Setiap Bulan

3 Waktu Kehadiran 

a. Pagi
11
35,5
b. Sore
8
25,8
c. Pagi dan Sore
12
38,7

Keterangan : $\mathrm{n}=$ jumlah responden

Hasil penelitian menunjukkan status kepemilikan apotek se-Kabupaten Pemalang milik sendiri $(61,3 \%)$ dan milik pemodal $(38,7 \%)$. Menurut classical theory of managerial tipe kepemilikan dapat mempengaruhi kinerja dari perusahaan. Perusahaan yang dikelola sendiri akan menghasilkan kinerja yang lebih baik dibandingkan dengan perusahaan yang dikelola oleh managemen [9]. Dari tabel 2 maka bisa dilihat bahwa milk sendiri persentase yang diperoleh lebih banyak dibandingkan dengan milik pemodal. Dengan demikian apotek yang milik sendiri akan memiliki kualitas pelayanan kefarmasian yang lebih baik dibandingkan dengan apotek pemodal.Secara umum apotek milik pemodal biasanya lebih mengutamakan untung atau sisi bisnis dibandingkan dengan kualitas pelayanan kefarmasian yang sesuai dengan standar.

Hasil dari penelitian menunjukkan frekuensi kehadiran apoteker di apotek yaitu setiap hari sebanyak (51,6\%), kurang dari 3x seminggu sebanyak (32,3\%) dan 1x setiap 2 minggu sebanyak $(16,1 \%)$. Waktu kehadiran pagi sebanyak $(35,5 \%)$, sore sebanyak $(25,8 \%)$, dan pagi sore $(38,7 \%)$. Pada penelitian Apriansyah (2018) didapatkan hasil frekuensi kehadiran sebanyak (34\%) tidak hadir pagi dan sore melainkan hanya hadir pada saat pagi dan sore hari saja [10]. Frekuensi kehadiran apoteker di apotek berkaitan dengan kualitas pelayanan kefarmasian di apotek, semakin tinggi frekuensi kehadiran di apoteker di apotek maka akan semakin meningkat kualitas pelayanan farmasi klinik [8].

\section{Tabel III. Karakteristik Apoteker}

\begin{tabular}{|c|c|c|c|}
\hline No & Variabel & $\begin{array}{l}\text { Jumlah } \\
(\mathbf{n}=31)\end{array}$ & $\begin{array}{c}\text { Persentase } \\
(\%)\end{array}$ \\
\hline 1 & Umur Apoteker & & \\
\hline & $\begin{array}{l}\text { a. 17-24 tahun } \\
\text { b. 25-30 tahun } \\
\text { c. }>31\end{array}$ & $\begin{array}{l}- \\
12 \\
19\end{array}$ & $\begin{array}{c}- \\
38,7 \\
61,3\end{array}$ \\
\hline 2 & $\begin{array}{l}\text { Jenis Kelamin } \\
\text { a. Laki-laki } \\
\text { b. }\end{array}$ & $\begin{array}{c}8 \\
23\end{array}$ & $\begin{array}{l}25,8 \\
74,2\end{array}$ \\
\hline 3 & $\begin{array}{l}\text { Pendidikan } \\
\begin{array}{ll}\text { a. } & \text { S1 + Profesi } \\
\text { b. } & \text { S2 + Profesi } \\
\text { c. } & \text { S3 + Profesi }\end{array}\end{array}$ & $\begin{array}{c}30 \\
- \\
1\end{array}$ & $\begin{array}{c}93,5 \\
- \\
6,5\end{array}$ \\
\hline
\end{tabular}

Hasil menunjukan umur responden untuk apoteker yang berada di apotek se-Kabupaten Pemalang yaitu 17-24 tahun sebanyak (-), 25-30 tahun sebanyak (38,7\%), >31 tahun sebanyak $(61,3 \%)$. Tabel 3 diatas menjelaskan bahwa apoteker berada dalam rentang usia $>31$ tahun dimana rentang usia tersebut merupakan usia produktif untuk masa kerja seseorang. Menurut penelitian yang dilakukan Harvard Groth Study proses perkembangan dan pertumbuhan diawali dengan usia remaja dan mencapai puncak 40 tahun. Pada kategori jenis kelamin responden mayoritas perempuan dengan persentase $(74,2 \%)$ dan untuk laki-laki $(25,8 \%)$. Untuk kategori pendidikan terakhir responden dapat dilihat dari Tabel 3 bahwa hampir keseluruhan responden memiliki pendidikan terakhir S1 yang memiliki gelar Apoteker dengan tahun lulusan yang berbeda. Menurut penelitian Apriansyah [10] responden yang mempunyai tingkat pendidikan yang tinggi cenderung pengetahuan yang baik. 


\subsection{Pengkajian dan Pelayanan Resep}

Tabel IV. Pengkajian dan Pelayanan Resep

\begin{tabular}{llll}
\hline \multirow{2}{*}{ No } & \multicolumn{1}{c}{ Variabel } & \multicolumn{2}{c}{ Persentase } \\
\cline { 3 - 4 } & \multicolumn{1}{c}{ Ya } & Tidak \\
\hline 1 & $\begin{array}{l}\text { Adakah SPO tentang pengkajian dan pelayanan resep } \\
\text { Referensi SPO pengkajian dan pelayanan resep diambil } \\
\text { dari Petunjuk Teknis Standar Pelayanan Kefarmasian di }\end{array}$ & - & 106,8 \\
& $\begin{array}{l}\text { Apotek 2019 } \\
\text { Apakah apoteker sering melakukan pengkajian dan } \\
\text { pelayanan resep }\end{array}$ & 90,3 & 9,7 \\
4 & $\begin{array}{l}\text { Tahap alur pelayanan resep yaitu penerimaan, } \\
\text { pemeriksaan sediaan, penyiapan sediaan farmasi, } \\
\text { peracikan obat, penyerahan obat dan informasi obat }\end{array}$ & 6,5 \\
5 & $\begin{array}{l}\text { Reaksi obat yang tidak diinginkan termasuk dalam } \\
\text { kajian kesesuaian farmasetik }\end{array}$ & 67,7 & 32,3 \\
\hline
\end{tabular}

Berdasarkan hasil penelitian pengkajian dan pelayanan resep terdapat SPO tentang pengkajian dan pelayanan resep maka dari itu didapatkan hasil presentase $96,8 \%$ artinya dari 31 apotek yang belum terdapat SPO ada 3,2\%. Sebanyak $100 \%$ dari 31 apotek belum mengetahui referensi terbaru, dilakukan wawancara beberapa apoteker menggunakan referensi lama yaitu Peraturan Menteri Kesehatan (PERMENKES) No 73 tahun 2016 tentang pelayanan farmasi klinik di apotek [11]. Menurut Peraturan Pemerintah No 51 tentang Pekerjaan Kefarmasian pasal 11 [12] Standar Prosedur Operasional harus dibuat secara tertulis dan diperbaharui secara terus menerus sesuai dengan perkembangan ilmu pengetahuan dan teknologi dibidang farmasi dan sesuai dengan ketentuan peraturan perundang undangan.

Apoteker yang melakukan pengkajian dan pelayanan didapatkan hasil 90,3\%. Tahap alur pelayanan resep yaitu penerimaan, pemeriksaan sediaan, penyiapan sediaan farmasi, peracikan obat, penyerahan obat dan informasi obat, apoteke dan TTK mengetahui urutan tahap alur pelayanan resep hal ini dapat dilihat dari persentasenya yaitu $93,5 \%$. Reaksi obat yang tidak diinginkan termasuk dalam kajian keseuian farmasetik didapatkan hasil $67,7 \%$. Sehingga dapt disimpulkan hasil penelitian pengkajian dan pelayanan resep di apotek se-Kabupaten Pemalang dikatakan baik.

\subsection{Dispensing}

Tabel V. Dispensing

\begin{tabular}{|c|c|c|c|}
\hline \multirow[t]{2}{*}{ No } & \multirow[t]{2}{*}{ Variabel } & \multicolumn{2}{|c|}{$\begin{array}{l}\text { Persentase } \\
(\%)\end{array}$} \\
\hline & & Ya & Tidak \\
\hline 1 & Adakah SPO tentang dispensing obat bebas & 80,6 & 19,4 \\
\hline 2 & $\begin{array}{l}\text { Referensi SPO dispensing diambil dari Petunjuk Teknis } \\
\text { Standar Pelayanan Kefarmasian di Apotek } 2019\end{array}$ & - & 100 \\
\hline 3 & $\begin{array}{l}\text { Tahap dispensing yaitu penyiapan, penyerahan dan } \\
\text { pemberian informasi obat }\end{array}$ & 100 & - \\
\hline 4 & $\begin{array}{l}\text { Apakah apoteker harus memberikan edukasi kepada } \\
\text { pasien yang memberikan obat non resep }\end{array}$ & 100 & - \\
\hline 5 & Apakah apoteker sering membuat salinan resep & 83,9 & 16,1 \\
\hline
\end{tabular}

Berdasarkan hasil dari penelitian dispensing terdapat SPO tentang dispensing didapatkan hasil presentase 80,6\% artinya dari 31 apotek yang belum terdapat SPO ada 19,4\%. Sebanyak 100 $\%$ dari 31 apotek belum mengetahui referensi terbaru, dilakukan wawancara beberapa apoteker 
menggunakan referensi lama yaitu PERMENKES No 73 tahun 2016 tentang pelayanan farmasi klinik di apotek [11]. Apoteker belum mengetahui untuk peraturan kementerian kesehatan yang terbaru. Menurut Peraturan Pemerintah No 51 tentang Pekerjaan Kefarmasian pasal 11 [12] Standar Prosedur Operasional harus dibuat secara tertulis dan diperbaharui secara terus menerus sesuai dengan perkembangan ilmu pengetahuan dan teknologi dibidang farmasi dan sesuai dengan ketentuan peraturan perundang undangan.

Tahap dispensing penyiapan, penyerahan dan pemberian informasi obat didapatkan hasil presentase $100 \%$, artinya apoteker dan TTK sufah mengetahui tahapan disepensing dan sudah dilakukan dengan baik. . Apoteker harus memberikan edukasi kepada pasien yang memerlukan obat non resep didapatkan presentase sebesar $100 \%$. Apoteker sering membuat salinan resep didapatkan hasil $83,9 \%$.

\subsection{Pelayanan Informasi Obat (PIO)}

Tabel VI. Pelayanan Informasi Obat

\begin{tabular}{clcc}
\hline \multirow{2}{*}{ No } & \multicolumn{1}{c}{ Variabel } & \multicolumn{2}{c}{$\begin{array}{c}\text { Persentase } \\
(\mathbf{\%})\end{array}$} \\
\cline { 2 - 4 } & \multicolumn{1}{c}{ Ya } & Tidak \\
\hline 1 & $\begin{array}{l}\text { Adakah SPO tentang pelayanan informasi obat bebas } \\
\text { Referensi SPO Pelayanan Informasi Obat diambil dari } \\
2\end{array}$ & - & 100 \\
& $\begin{array}{l}\text { Petunjuk Teknis Standar Pelayanan Kefarmasian di } \\
\text { Apotek 2019 }\end{array}$ & & \\
3 & $\begin{array}{l}\text { Apakah apoteker atau TTK sering menjelaskan waktu } \\
\text { penggunaan obat kepada pasien }\end{array}$ & 100 & - \\
4 & $\begin{array}{l}\text { Apakah apoteker atau TTK sering menyebutkan nama } \\
\text { obat yang diberikan kepada pasien }\end{array}$ & 100 & - \\
5 & $\begin{array}{l}\text { Apakah apoteker atau TTK sering menjelaskan cara } \\
\text { penyimpanan obat kepada pasien }\end{array}$ & 83,9 & 16,1 \\
\hline
\end{tabular}

Berdasarkan hasil dari penelitian pelayanan infomasi obat apoteker mengemukakan sudah terdapat SPO tentang pelayanan informasi obat maka dari itu didapatkan hasil presentase $77,4 \%$ artinya dari 31 apotek yang belum terdapat SPO ada 22,6\%. Referensi pelayanan informasi obat apoteker mengemukakan bahwa referensi mengambil dari PERMENKES No 73 tahun 2016 tentang pelayanan farmasi klinik di apotek [11], apoteker mengemukakan bahwa tidak mengetahui peraturan yang terbaru yaitu petunjuk teknis standar pelayanan kefarmasian pada tahun 2019. Menurut Peraturan Pemerintah No 51 tentang Pekerjaan Kefarmasian pasal 11 [12] Standar Prosedur Operasional harus dibuat secara tertulis dan diperbaharui secara terus menerus sesuai dengan perkembangan ilmu penegtahuan dan teknologi dibidang farmasi dan sesuai dengan ketentuan peraturan perundang undangan. Maka kesimpulannya apoteker masih belum mengetahui untuk peraturan kementerian kesehatan yang terbaru.

Apoteker atau TTK sering menjelaskan waktu penggunaan obat kepada pasien menghasilkan presentase $100 \%$. Apoteker atau TTK sering menyebutkan nama obat yang diberikan menghasilkan presentase $100 \%$ dan apoteker atau TTK sering menjelaskan cara penyimpanan obat kepada pasien menghasilkan presentase 83,9\%. Pemberian informasi ini sangat diperhatikan oleh apoteker karena melalui pemberian informasi apoteker dapat meminimalisasi terjadinya medication error yang mungkin dilakukan oleh pasien pada saat mengkonsumsi obat. Dari penelitian tersebut dapat disimpulkan bahwa hasil penelitian dari SPO pelayanan informasi obat sudah diterapkan dengan baik.

\subsection{Konseling}


Tabel VII. Konseling

\begin{tabular}{|c|c|c|c|}
\hline \multirow[t]{2}{*}{ No } & \multirow{2}{*}{ Variabel } & \multicolumn{2}{|c|}{$\begin{array}{l}\text { Persentase } \\
(\%)\end{array}$} \\
\hline & & Ya & Tidak \\
\hline 1 & Adakah SPO tentang konseling tentang pasien pediactric & 80,6 & 19,4 \\
\hline 2 & $\begin{array}{l}\text { Referensi SPO Konseling diambil dari Petunjuk Teknis } \\
\text { Standar Pelayanan Kefarmasian di Apotek } 2019\end{array}$ & - & 100 \\
\hline 3 & Apakah apoteker atau TTK mengetahui three prime question & 71 & 29 \\
\hline 4 & $\begin{array}{l}\text { Apakah apoteker atau TTK mengetahui metode Health Belief } \\
\text { Model }\end{array}$ & 32,3 & 67,7 \\
\hline 5 & $\begin{array}{l}\text { Apakah penyakit seperti TB, Epilepsi, DM, dan AIDS perlu } \\
\text { dilakukan konseling }\end{array}$ & 74,2 & 25,8 \\
\hline
\end{tabular}

Hasil dari penelitian dihasilkan bahwa di apotek daerah Kabupaten Pemalang sudah menjalankan SPO konseling dengan baik karena dihasilkan persentase sebesar 80,6\%. Referensi pelayanan informasi obat apoteker mengemukakan bahwa referensi mengambil dari PERMENKES No 73 tahun 2016 [11] tentang pelayanan farmasi klinik di apotek, apoteker mengemukakan bahwa tidak mengetahui peraturan yang terbaru yaitu petunjuk teknis standar pelayanan kefarmasian pada tahun 2019. Menurut Peraturan Pemerintah No 51 tentang Pekerjaan Kefarmasian pasal 11 [12[ Standar Prosedur Operasional harus dibuat secara tertulis dan diperbaharui secara terus menerus sesuai dengan perkembangan ilmu pengetahuan dan teknologi dibidang farmasi dan sesuai dengan ketentuan peraturan perundang undangan.

Untuk mengawali konseling biasanya apoteker menggunakan three prime question, pertanyaan tersebut sebagai berikut yaitu apa yang dokter katakan tentang obat anda? Selanjutnya apa yang dokter jelaskan tentang harapan setelah minum obat ini? Dan bagaimana cara penjelasan dokter tentang obat ini?. Pertanyaan diatas dilakukan dengan tujuan agar tidak terjadi pemberian informasi yang tumpang tindih, mencegah pemberian informasi yang bertentangan informasi yang disampaikan oleh dokter dan untuk mengetahui sejauh mana pengetahuan dan kemampuan pasien dalam menjalani pengobatan. Dalam hal ini didapatkan hasil dari apoteker atau TTK mengetahui three prime question didapatkan hasil $71 \%$.

Health belief model adalah model yang mendefinisikan bagaimana individu secara kognitif menunjukan perilaku yang sehat maupun usaha untuk menuju sehat dalam suatu penyakit [9]. Dalam penelitian ini didapatkan hasil apoteker maupun TTK mengetahui Health Belief Model ini didapatkan hasil 32,3\% untuk apoteker dan TTK yang mengetahui metode health belief model ini. Dalam petunjuk teknis standar pelayanan kefarmasian di apotek tahun 2019 menyebutkan bahwa untuk penderita penyakit kronis seperti TBC, DM, AIDS dan Epilepsi harus diberikan konseling secara berkelanjutan. Penderita penyakit tersebut membutuhkan jangka waktu pengobatan yang tidak sekali atau dua kali tetapi membutuhkan jangka waktu yang panjang. Untuk dapat sembuh dan harus teratur meminum obat yang telah diberikan, karena itulah apoteker seharusnya memberikan perhatian yang tepat kepada mereka. Dalam hal ini didapatkan hasil kuisioner perlu melakukan konseling untuk penyakit kronis seperti TBC, DM, AIDS dan Epilepsi didapatkan persentase 74,2\% hal ini sudah termasuk baik.

\subsection{Pelayanan Kefarmasian di rumah}

Tabel VIII. Pelayanan Kefarmasian di rumah

\begin{tabular}{lcc}
\hline \multirow{2}{*}{ No } & Variabel & $\begin{array}{c}\text { Persentase } \\
(\%)\end{array}$ \\
\cline { 2 - 3 } & & Ya Tidak \\
\hline
\end{tabular}




\begin{tabular}{lllll}
\hline 1 & Adakah SPO tentang pelayanan kefarmasian dirumah & 64,5 & 35,5 \\
2 & $\begin{array}{l}\text { Referensi SPO pelayanan kefarmasian dirumah } \\
\text { diambil dari Petunjuk Teknis Standar Pelayanan }\end{array}$ & & 100 \\
Kefarmasian di Apotek 2019 & & & \\
3 & $\begin{array}{l}\text { Apakah apoteker atau TTK sering melakukan } \\
\text { kunjungan di rumah } \\
\text { Apakah apoteker atau TTK sering melakukan } \\
\text { pendampingan pengelolaan obat di rumah misalnya } \\
\text { penyimpanan insulin dll } \\
\text { Apakah apoteker sering melakukan monitoring } \\
\text { pelaksanaan efektifitas dan keamanan penggunaan } \\
\text { obat berdasarkan catatan pengobatanpasien dirumah }\end{array}$ & 83,2 & 96,8 \\
&
\end{tabular}

Berdasarkan hasil dari penelitian yang terkait SPO tentang pelayanan kefarmasian di rumah telah didapatkan hasil presentase $64,5 \%$ artinya dari 31 apotek yang belum terdapat SPO ada $35,5 \%$. Sebanyak $100 \%$ dari 31 apotek belum mengetahui referensi terbaru, dilakukan wawancara beberapa apoteker menggunakan referensi lama yaitu PERMENKES No 73 tahun 2016 tentang pelayanan farmasi klinik di apotek [11]. Apoteker belum mengetahui untuk peraturan kementerian kesehatan yang terbaru. Menurut Peraturan Pemerintah No 51 tentang Pekerjaan Kefarmasian pasal 11 [12] Standar Prosedur Operasional harus dibuat secara tertulis dan diperbaharui secara terus menerus sesuai dengan perkembangan ilmu pengetahuan dan teknologi dibidang farmasi dan sesuai dengan ketentuan peraturan perundang undangan.

Pada penelitian ini apoteker yang melakukan kunjungan ke rumah pasien mendapatkan hasil sebanyak 19,4\% untuk melakukan pendampingan dan tidak melakukan pendampingan sebanyak 80,6\%. Beberapa apoteker mengemukakan tidak melakukan pelayanan kefarmasian dirumah karena Apoteker atau TTK mempunyai kesibukan sendiri. Pada penelitian ini apoteker yang melakukan pendampingan pengelolaan obat di rumah misalnya penyimpanan insulin, didapatkan hasil sebanyak $16,1 \%$ artinya dari 31 apotek yang belum melakukan pendampingan pengelolaan obat di rumah sebanyak $83,9 \%$.

Pada penelitian ini apoteker yang melakukan monitoring pelaksaan efektifitas dan keamanan penggunaan obat berdasarkan catatan pengobatan pasien mendapatkan hasil sebanyak 3,2\% untuk melakukan monitoring pelaksanaan efektifitas dan keamanan penggunaan obat dan tidak melakukan pendampingan sebanyak 96,8\%. Hal ini dapat disimpulkan bahwa SPO pelayanan kefarmasian di rumah belum dilakukan dengan baik.

\subsection{Pemantauan Terapi Obat}

Tabel IX. Pemantauan Terapi Obat

\begin{tabular}{clcc}
\hline \multirow{2}{*}{ No } & \multicolumn{1}{c}{ Variabel } & \multicolumn{2}{c}{$\begin{array}{c}\text { Persentase } \\
(\boldsymbol{\%})\end{array}$} \\
\cline { 3 - 4 } & \multicolumn{1}{c}{ Ya } & Tidak \\
\hline 1 & $\begin{array}{l}\text { Adakah SPO tentang pemantauan terapi obat } \\
\text { terhadap pasien pediatrik }\end{array}$ & 67,7 & 32,3 \\
2 & $\begin{array}{l}\text { Referensi SPO pemantauan terapi obat diambil } \\
\text { dari Petunjuk Teknis Standar Pelayanan } \\
\text { Kefarmasian di Apotek 2019 }\end{array}$ & & \\
& & & \\
\end{tabular}


3

Apakah apoteker atau TTK sering melakukan wawancara terkait riwayat pengobatan, riwayat alergi dll

4

Apakah menerima obat yang sering diketahui menyebabkan reaksi obat yang merugikan termasuk kriterian pasien dalam pemantauan terapi obat.

5
$58,1 \quad 41,9$

$25,8 \quad 74,2$

$64,5 \quad 35,5$ termasuk kriteria pasien dalam pemantauan terapi obat.

Berdasarkan hasil dari penelitian pemantauan terapi obat terdapat SPO tentang pemantauan terapi obat didapatkan hasil presentase $67,7 \%$ artinya dari 31 apotek yang belum terdapat SPO ada $32,3 \%$. Sebanyak $100 \%$ dari 31 apotek belum mengetahui referensi terbaru, dilakukan wawancara beberapa apoteker menggunakan referensi lama yaitu PERMENKES No 73 tahun 2016 tentang pelayanan farmasi klinik di apotek [11]. Apoteker belum mengetahui untuk peraturan kementerian kesehatan yang terbaru. Menurut Peraturan Pemerintah No 51 tentang Pekerjaan Kefarmasian pasal 11 [12] Standar Prosedur Operasional harus dibuat secara tertulis dan diperbaharui secara terus menerus sesuai dengan perkembangan ilmu penegtahuan dan teknologi dibidang farmasi dan sesuai dengan ketentuan peraturan perundang undangan.

Apoteker dan TTK sering melakukan wawancara terkait riwayat pengobatan, riwayat alergi dan lain lain didapatkan hasil persentasi $58,1 \%$ artinya dari 31 apotek yang tidak melakukan wawancara terkait pengobatan, riwayat alergi, riwayat penyakit sebanyak 41,9\%. Hal ini dari 31 apotek sudah melakukan dengan baik dalam melakukan wawancara terkait pengobatan pasien. Menerima obat yang sering diketahui menyebabkan reaksi obat yang merugikan termasuk kriteria pasien dalam pemantauan terapi obat didapatkan hasil persentasi $25, \%$ artinya dari 31 apotek yang tidak mengetahui tentang reaksi obat yang merugikan termasuk kriteria pasien dalam pemantauan terapi obat sebanyak $74,2 \%$. Hal ini dapat disimpulkan bahwa apoteker maupun TTK kurang memahami isi dari petunjuk teknis standar pelayanan kefarmasian.

Petunjuk teknis standar pelayanan kefarmasian di apotek dalam pemantauan terapi obat melakukan persiapan seleksi pasien yang bertujuan untuk menentukan prioritas pasien yang akan dipantau. Seleksi ini dapat dilakukan berdasarkan kriteria pasien salah satunya pasien dengan gangguan fungsi organ terutama hati dan ginjal. Didapatkan hasil persentasi 64,5\% artinya dari 31 apotek yang tidak mengetahui tentang pasien dengan ganguan ginjal dan hati termasuk kriteria pasien dalam pemantauan terapi obat sebanyak $35,5 \%$. Hal ini dikatakan bahwa apoteker maupun TTK sudah mengetahui teori dari panduan yang sudah ada. Dari penelitian tersebut dapat disimpulkan bahwa hasil penelitian dari SPO pemantauan terapi obat belum dilakukan dengan baik. Pada penelitian as-syifa didapatkan hasil pemantauan obat sebesar 78,3\% tidak dilakukan pemantauan obat oleh apoteker dan dilakukan pemantauan obat oleh apoteker sebesar 19,9\%.

\subsection{Monitoring Efek Samping Obat}

Tabel X. Monitoring Efek Samping Obat

\begin{tabular}{clll}
\hline \multirow{2}{*}{ No } & \multicolumn{1}{c}{ Variabel } & \multicolumn{2}{c}{$\begin{array}{c}\text { Persentase } \\
(\mathbf{\%})\end{array}$} \\
\cline { 3 - 4 } & \multicolumn{1}{c}{ Ya } & Tidak \\
\hline 1 & Adakah SOP tentang Monitoring efek samping obat & 32,3 & 67,7 \\
2 & $\begin{array}{l}\text { Referensi SOP Monitoring Efek Samping Obat } \\
\text { diambil dari Petunjuk Teknis Standar Pelayanan }\end{array}$ & & 100 \\
& $\begin{array}{l}\text { Kefarmasian di Apotek 2019 } \\
\end{array}$ & &
\end{tabular}

Jurnal Ilmiah Jophus Vol. 03, No. 01, Agustus 2021 : 64 - 74 
3 Apakah ada formulir tentang memonitoring efek $61,3 \quad 38,7$ samping obat

$4 \quad$ Apakah kerja sama yang baik termasuk faktor yang $32,3 \quad 67,7$ diperhatikan dalam MESO

5 Apakah apoteker atau TTK sering melakukan 54,8 45,2 monitoring efek samping obat

Berdasarkan hasil dari penelitian memonitoring efek samping obat terdapat SPO tentang memonitoring efek samping obat obat didapatkan hasil presentase 32,3\% artinya dari 31 apotek yang belum terdapat SPO ada 67,7\%. Sebanyak $100 \%$ dari 31 apotek belum mengetahui referensi terbaru, dilakukan wawancara beberapa apoteker menggunakan referensi lama yaitu PERMENKES No 73 tahun 2016 tentang pelayanan farmasi klinik di apotek [11]. Apoteker belum mengetahui untuk peraturan kementerian kesehatan yang terbaru. Menurut Peraturan Pemerintah No 51 tentang Pekerjaan Kefarmasian pasal 11 [12] Standar Prosedur Operasional harus dibuat secara tertulis dan diperbaharui secara terus menerus sesuai dengan perkembangan ilmu pengetahuan dan teknologi dibidang farmasi dan sesuai dengan ketentuan peraturan perundang undangan. Maka hal ini dikatakan belum baik, sejumlah 31 apotik belum melakukan pembaruan referensi SPO dan tidak membuat SPO tentang MESO.

Dari data diatas menunjukkan terdapat formulir tentang monitoring efek samping obat didapatkan hasil $61,3 \%$ yang memiliki formulir menitoring efek samping obat dan tidak memiliki formulir terdapat $38,7 \%$. Hal ini dari 31 apotik di Kabupaten Pemalang dikatakan sudah cukup baik karena memiliki formulir tentang monitoring efek samping obat. Dalam buku petunjuk teknis standar pelayanan kefarmasian di apotek faktor faktor yang harus perlu diperhatikan yaitu kerjasama dengan tim kesehatan lain dan ketersediaan formulir Monitoring Efek Samping Obat (MESO). Didapatkan hasil presentase $32,3 \%$ artinya dari 31 apotek yang belum mengetahui tentang kerja sama yang baik termasuk faktor yang diperhatikan dalam MESO sebanyak 67,7\%. Hal ini menunjukkan apoteker maupun TTK tidak mengetahui isi dari peraturan yang sudah tertulis. Selanjutnya apoteker atau TTK yang melakukan monitoring efek samping obat didapatkan hasil $54,8 \%$.

\section{KESIMPULAN}

Hasil penelitian menunjukkan bahwa apotek yang memiliki SPO berdasarkan Petunjuk Teknis Standar Pelayanan Kefarmasian di Apotek 2019 yaitu SPO Pengkajian dan Pelayanan Resep (96,8\%), SPO Dispensing (80,6\%), SPO Pelayanan Informasi Obat (77,4\%), SPO Konseling $(80,6 \%)$, SPO Pelayanan Kefarmasian di Rumah (64,5\%), SPO Pemantauan Terapi Obat $(67,7 \%)$, SPO Memonitoring Efek Samping Obat $(32,2 \%)$. Berdasarkan penelitian yang dilakukan pelayanan farmasi klinik di apotek se-Kabupaten Pemalang sudag berjalan cukup baik.

\section{DAFTAR PUSTAKA}

[1] P. dkk Arnani, Langkah langkah Efektif Menyusun SPO Standar Operating Procudures. Depok: Huta Publisher, 2016.

[2] D. Setiawan, "Analisa Standar Operasional Prosedur CV. Apotek Lawang Gali," J. Agora, vol. 6, no. 1, hal. 1-7, 2018.

[3] S. Ihsan, P. Rezkya, dan N. I. Akib, "Evaluasi Mutu Pelayanan di Apotek Komunitas Kota Kendari Berdasarkan Standar Pelayanan Kefarmasian," J. Farm. dan Ilmu Kefarmasian, vol. 1, no. 2, hal. 30-35, 2014.

[4] Kementrian Kesehatan, Petunjuk Teknis Standar Pelayanan Kefarmasian di Apotek. Jakarta: Kementerian Kesehatan Republik Indonesia, 2019.

[5] M. Nazir, Metodologi Penelitian. Bogor: Ghalia Indonesia, 2011.

[6] Notoatmodjo, Metodologi Penelitian Kesehatan. Jakarta: Rineka Cipta, 2013. 
[7] Sugiyono, Metode Penelitian Kuantitatif Kualitatif dan Kombinasi (Mixed Methods). Bandung: Alfabeta, 2016.

[8] R. Kwando, "Pementaan Peran Apoteker dalam Pelayanan Kefarmasian Terkait Frekuensi Kehadiran Apoteker di Surabaya Timur," J. Ilm., vol. 3, no. 1, hal. 1-12, 2014.

[9] Sugiyono, Metode Penelitian Kuantitatif. Bandung: Alfabeta, 2018.

[10] A. Apriansyah, Y. Saibi, dan Karyadi, "Gambaran Pelayanan Farmsi Klinik di Apotek Wilayah Kota Tanggerang Selatan," J. Pharmacopolium, vol. 1, no. 2, hal. 81-87, 2018.

[11] Peraturan Menteri Kesehatan (PERMENKES) No 73 Tahun 2016 Tentang Pelayanan Farmasi Klinik Di Apotek.

[12] Peraturan Pemerintah No 51 Tentang Pekerjaan Kefarmasian. 